This item was submitted to Loughborough's Research Repository by the author.

Items in Figshare are protected by copyright, with all rights reserved, unless otherwise indicated.

\title{
International migration: transit space - creative space?
}

PLEASE CITE THE PUBLISHED VERSION

https://doi.org/10.1504/IJMBS.2017.083218

\section{PUBLISHER}

() Inderscience

\section{VERSION}

AM (Accepted Manuscript)

\section{PUBLISHER STATEMENT}

This work is made available according to the conditions of the Creative Commons Attribution-NonCommercialNoDerivatives 4.0 International (CC BY-NC-ND 4.0) licence. Full details of this licence are available at: https://creativecommons.org/licenses/by-nc-nd/4.0/

\section{LICENCE}

CC BY-NC-ND 4.0

\section{REPOSITORY RECORD}

Oelgemoller, Christina. 2017. “International Migration: Transit Space - Creative Space?”. Loughborough University. https://hdl.handle.net/2134/20669. 


\title{
International migration: transit space - creative space?
}

\section{Christina Oelgemöller}

Department of Politics, History and International Relations, School of Social, Political and Geographical Sciences,

Loughborough University,

LE113TU, UK

Email: e.c.oelgemoller@lboro.ac.uk

\begin{abstract}
Is it possible to make illegal migrants intelligible as a force creating social space? What is transit space? Many migration experts seem to ignore the transit space beyond managing geopolitical borders. Much literature analyses this space in terms of the migrant's (in)capacity to act. I argue that transit space policies make possible both a particular kind of illegality of the transit space and ephemeral spaces of solidarity/creativity quite different from the places of citizenship (accorded or denied). Geopolitical transit space is intrinsically important to understanding how contradictory mobility practices are constructed. My speculation is informed by a postanarchist perspective and draws on selected ethnographic studies for illustration. Approaching transit space as contradictory constellation makes it political, in that abstract logics imposed by the European discursive order interact with ephemeral practices, producing violence and solidarity in a way that throws what is licit and illicit open to radical questioning.
\end{abstract}

Keywords: illegal migrant; illicit activity; transit space; worldliness; Arendt; political; ephemeral; imaginary; authority; autonomy; EU; Maghreb; Global North; Global South.

Reference to this paper should be made as follows: Oelgemöller, C. (xxxx) 'International migration: transit space - creative space?', Int. J. Migration and Border Studies, Vol. X, No. Y, pp.xxx-xxx.

Biographical notes: Christina Oelgemöller is a Lecturer in International Relations at Loughborough University, with research driven by an interest in the intersections of international doctrine formation, political subjectivity of ephemeral populations and forms of radical democracy. She has substantial teaching, supervision and pastoral care experience at both postgraduate and undergraduate levels. She draws on many years of administrative experience within higher education and beyond, most notably through nearly ten years of social policy practice.

\section{Introduction}

In European policy narratives, transit spaces have never been more significant than during the first half of 2015. Currently, we are witnessing a media frenzy and government hand-wringing about the Mediterranean, about how people lose their lives in the process of transiting and about how many people push their way into Europe seeking sanctuary. 
This is not a new phenomenon, but it has become a quantitatively significant phenomenon in part because of the political situation in the Middle East. Yet the narrative about international migration treats the transit space as largely unimportant so long as these spaces are not part of the European territory (Schapendonk, 2009, 2012). The application of transit space as policy tool is a fair-weather phenomenon creating illegal migrants. By contrast, the second half of 2015 it became clear that much of the movement was for the purpose of finding protection. Some of Europe accepts refugees. But, what happens when this crisis ends? Or what happens when European borders are closed again, as is happening in most current developments, because people and services cannot cope? Does transit space regain significance as a policy tool? What is transit space? How can it be understood and what does it do?

When it comes to international migration, the standard approach amongst many policy makers is still only to problematise the beginning of the journey and its assumed end. The idea that migration can be explained by a typology of push and pull factors, with people moving away from troubled spaces marked by strife and/or poverty towards spaces of affluence that draw people in, remains highly attractive (Faist, 2012). Such formulation of the 'problem' has resulted in the idea of 'mixed flows' that congregate in transit spaces (Mountz and Kempin, 2014). As a result, policy focuses on how to rid ourselves of the problem via return (Wolff, 2014) or resettlement, for example, to North America (Ambroso, 2012). From the perspective of European Governments, transit spaces are marginal spaces from which attempts are made to access the European Union in illegal fashion. Accordingly EU Governments, security experts and inter-governmental and non-governmental organisations try to stop such endeavours, exercising what van Houtum (2010) calls the 'global apartheid of the EU's external border regime'. In this conceptualisation, transit spaces have no importance in themselves - they are just the space that people pass through, or, better, are stopped in or turned back to, constituting part of the Global South rather than the Global North.

The academic literature is more nuanced than the media and policy narratives. Here, we find the transit space and its use by the global policy community critically appraised from a historical perspective, from a perspective of geographic and ethnographic considerations and their political ramifications (Collyer et al., 2012). We also find problematisations that are spatially oriented more clearly and focus on the symbiotic relationship between enforcement of border control on the one hand and illicit economic activity of a growing industry to facilitate migration on the other, as well as on the effects this has on southern European countries which encounter illegal migrants ${ }^{1}$ first [Mountz and Kempin, (2014), p.85]. This literature is important. First, it sets out what is deeply problematic about 'transit migration' as a seemingly homogenous concept that hides the very diverse people, motivations for migration, and the heterogeneous ways people find their way towards the edges of those affluent spaces they want to access (Collyer and de Haas, 2012). Second, it reveals itself as somewhat Eurocentric, as it formulates the problem from a European perspective and does not take into account that someone in, for example, Morocco or Turkey may have actually aimed to be in that country rather than aiming to move on to European territory (Collyer et al., 2012). Third, it explores 'transit' as such - not actually a new concept, but new to the generation of experts of the new migration of the past 20 years (Bredeloup, 2012) - and how transit spaces affect a migrants' ability to claim access, protection, status and a voice. Tazzioli explains that "the migration regime brings to the fore an issue concerning the spatial ontology of governmentality" [Tazzioli, (2015), p.5 (italics in the original)]. Tazzioli goes on to point 
out that this new migration field "is formed by a heterogeneous production of spaces and works through the articulation of different spatial regimes" [Tazzioli, (2015), p.5].

What characterises this new migration of the late 20th century? Calling international migration during this period 'new' is justified by most literature in changes such as the collapse of the USSR, new wars and broader changes to the global order propelled by globalisation (here mainly but not exclusively understood in its economic incarnation), and the EU's increased relations with its neighbours (Koser and Lutz, 1999; Düvell, 2005; Betts and Milner, 2006). The drivers for European bureaucrats problematising this 'new' migration negatively, rather than positively as an opportunity for enrichment (through ideas, etc.), have been rising narratives of fear about the disruption of cultural and social homogeneity. These narratives have come to be embodied in arguments over loss of control over mobility and the resultant exploitation of European systems of freedom and protection (most often expressed through fear of welfare abuse). So the space in these narratives is invested with negative potential bringing about threats to Europe's security.

Discursively, an awareness of transit space has involved diversification of classifications and conceptual innovation. For example, ideas have been introduced of 'secondary onward movement' which leads to 'mixed flows' accumulating in 'transit countries'. These depictions enable the logic of 'illegal migration' by establishing a seemingly homogenous grouping around unidentified commonalities involving illegality, high risk, lack of control and an assumption that everybody who is on the move from 'elsewhere' is bound for Europe (Collyer et al., 2012). As Jones (2009) observes, this discourse of boundary drawing and maintaining requires a lot of technocratic effort to sustain the perception that we, as Europeans, are threatened. ${ }^{2}$

What seems interesting to me is the argument made in the literature that technological advancement both facilitates and brings new possibilities for inhibiting movement. As elaborated in the following sections, I am not so much interested here in how this changes old and new routes of mobility [as explored, for example, by Carling (2007), Collyer (2010) and de Haas $(2006,2008)]$, but in how the dynamic of facilitating and inhibiting mobility by different actors creates in these transit spaces new social spaces of both violence and solidarity. With this emerges an embryonic politics of a 'world apart', rather than a 'world without' as imagined by European policy makers and constructors of this space. I draw on earlier work, in which I have shown how European policy-making narratives have first constructed our contemporary meaning of the 'transit country' and, in doing so, made the 'illegal migrant' intelligible and actionable in the first place (Oelgemöller, 2010), ${ }^{3}$ and go beyond it here to thinking about what constitutes space in the context of transit.

I argue that transit spaces are important to think about in their own right. There is significant research that shows not only that there is quite a lot going on in the transit space, but also, more significantly, that transit space is imbued with questions of authority and contest, and is productive of a particular kind of the social. Transit space is not an unimportant 'space without'; it is here conceptualised as 'space apart' - not a country with a clearly defined perimeter, but unbound space diffusely and flexibly opening out. In this sense transit space is productive of abandonment and abjection, as much of the academic literature very importantly shows; but I want to focus on the following-on transit space, at least speculatively, as constituting the possibility of autonomous spaces of ephemeral political action outside the straightjacket of imposed 
governance driven by policies of the European Union and, more generally, countries of the Global North. I thus draw on Lefebvre and Arendt to help me understand transit space conceptually as creative space in which what is legitimate is shifting and marked by different kinds of violence where people actively engage. In order to do so, I first review briefly the dominant imaginings of transit space as starting 'without', but essentially diffuse and impenetrable. I then ask what space is by invoking different authorities, not as an exercise in political thought but in order to discuss the relationship between space and ephemeral acts of autonomy, which leads into a review of how activities otherwise understood as abject and/or illicit bring about such ephemeral spaces of equality and freedom.

\section{Diffuse and impenetrable spaces 'without' - European imaginings}

The space considered here is the space constructed in the context of international migration of the late 20th century, which is a rather recent phenomenon, at least in terms of its 'expert' attention. I use 'expert' with reference to migration management 'experts', which include international organisations, such as the IOM, European bureaucrats and security technicians (Bigo, 2014). These spatial knowledge practices are not exclusively relevant to the European Union and its geopolitical relationships, though the transit space is most certainly an idea that began with the doctrine formation of European home affairs and police/border control officers in the 1980s (Oelgemöller, 2011). Here, I focus on the Maghreb for illustrative purposes, but strongly suggest that some of the empirical realities articulated here apply equally to spaces found in such locations as Australia, North America and their neighbourhoods.

\subsection{One-sided boundary drawing}

One question to be addressed is how it is possible that policy-making and some academic analysis are driven by an underlying assumption of 'space without'. Lefebvre (1991) suggests that historically there were two approaches to the analysis and understanding of space. First, there was the theoretical space, demarcated by cartographers. He writes "mathematicians appropriated space ... an 'indefinity' ... At once highly general and highly specialized, the language of mathematics set out to discriminate between and classify all these innumerable spaces as precisely as possible" [Lefebvre, (1991), p.2]. This is the space artificially drawn, ignoring the perceived and thus ignoring the common sense of living in space.

Second, there was the lived space, which is made accessible through imagination. Lefebvre labels this 'mental space', "which is apparently, but only apparently, extra-ideological" [Lefebvre, (1991), p.6] and criticises that this is a construction which, although lacking logical linkage, is separated from social practice and, therefore, remains a space created entirely as space of knowledge construction, devoid of substantive character and disintegrated. Constructing space like this is "a trend subordinated to a centre or to a centralized power and advanced by a knowledge which works as power's proxy" [Lefebvre, (1991), p.9]. In order for such theoretical space to 'work', abstraction and imagination are needed, in addition to the effort of thinking of space as something both vast and concrete. It is for this reason that I briefly illustrate Europe's imaginings of transit space below. 
Visual communication is discursively important. Many of the pictures we encounter in the press, even before the beginning of 2015, are of two kinds and may help us understand European imaginings. We see European uniformed men and military equipment (naval ships), in encounters with people of non-European origin. The European men handle women and children, imagined largely as victims, who are in subdued poses and needing to be physically supported and regulated. They are victims because they are weak and uprooted. This, seemingly, has nothing to do with ideology, but is a mere enactment of Lefebvre's space, made concrete by those victims appearing uninvited and problematic on 'our' doorstep. More often, we see young black men who attempt the illegal journey. They are, quite literally, a huddled mass in the images we see, confronted by European officials in uniform, who loom authoritatively. Here, too, we see a very concrete expression of Lefebvre's imagined mental space. The assumption in much of the imagery and its accompanying narrative is that these young black men are reckless towards themselves, to the families they have left behind, and towards the community of Europeans who are at risk of illegitimate exploitation. They travel in unseaworthy vessels, do not play by the rules of legitimate access and willingly endanger themselves and others. At the same time, there is an impression of vastness, of indefinite space, as they, the reckless men and the women and children, come from some unknown, unspecified place in great numbers. We see images not so much of individuals, but of cramped and crowded boats with lots of undefined, coloured bodies. A space is created that might then be used to induce fear - of overcrowding, of unknown people of unknown origin from unknown places.

Interestingly, those approaching the victims and young men are alien-looking people in uniforms that increasingly resemble the protective clothing of a pest controller. The choice of clothing plays a part in subtly communicating the myriad of fears to be felt from influences coming from 'without'. The uniform, in general, communicates important messages that feed into this imaginary. Objects such as clothing communicate meaning; they take particular subject positions and act as important tools to the European imaginings. The white 'pest suits' worn by border controllers at the edges of the European Union suggest cleanliness, emphasising the possibility of disease among those pressing to enter Europe. They make visible the difference between civilised Europeans and those victims and criminals. They communicate to the European citizen that possible threats are controlled. They also erase the individual identity of border controllers. They create easily differentiated groups, emphasising the boundaries in the encounter between the victims/criminals and the world of stability and health. Combining pest suits with military equipment emphasises the assumed threat emanating from these people; a mental space is constructed, demarcated by a space of quarantine and a space of safety for Europeans, which seems to need protection. The white suit makes visible the boundary at which transit space starts.

Such navel-gazing by the Global North is not only traceable in imagery; it is introduced by international organisations with a mandate for protection as well. Düvell (2012, p.417) thus shows how "a UN publication identifies transit migration with 'flows of irregular and illegal migrants from the Third World and from East European countries' UN/ECE (1993: 7) and stresses that transit migrants reach their destination 'by means that are partially, if not fully, illegal"'. This is constructed as a form of territorial invasion, which has been much discussed in the literature on migration and security (Weiner, 1992; Walters, 2004; Bigo, 2014; Huysmans, 2006; Squire, 2010; Doty, 2011; 
Hyndman and Mountz, 2008). Prosperous countries that exert their entitlement to authority freely (Lefebvre's centralised power), such as those of the Global North, thus set up the cause, justification and solution to this seemingly obvious problem of international migration, basing them on assumptions of rightful superiority. This perspective is spatial, insofar as the assumed destination is a defined place. Because of geographic proximity, the destination place needs protection by law and by military and public health measures, whilst anything that came before is not imagined in any particularity, being 'space without'.

\subsection{Space without}

Reading European policy documents highlights further how transit space is imagined as 'space without' - beyond the one-sided boundary demarcating the 'beginning' of the Global North with all its connotations of health, security and stability. Standards for enforcement action (including capacity-building measures funded through development funds) are set in such a way that the beginning (or end, depending on perspective) is clear, but the space acted upon is left diffuse, with the onus on the generalised 'partner'. Thus, the joint communication on implementing the European Neighbourhood Policy 2013 begins by stating "in the Southern Neighbourhood, the overall political situation [is] often hampered partner countries' readiness to implement the agreed reform agenda" [EC, (2014), p.4]. The operative phrasing here is 'partner countries' readiness to implement' reform, which reads, as elaborated in the example below, very much like a blueprint of neoliberal measures without apology, but with European values added to the mix. This is not surprising, given that neither Europe nor its southern Mediterranean 'partners' can easily withdraw from wider global dynamics. What is troubling is the use of language of incentivised policy and funding, indicating that these relationships are asymmetrical rather than egalitarian, and the imposition of values that Europe itself does not live up to, such as the avoidance of discrimination, protection of those in need and the extension of human rights (be they civic-political or socio-economic). Here the picture of space-making becomes a bit more complicated. Demarcation is imagined here, but it is one-sided; there is concrete space bounded on one side by the dividing line between the Southern 'partner' and the well-functioning European Union, but, importantly, there is diffuse and impenetrable (indefinite) space from the point where 'readiness of the partner to implement' is required.

To illustrate this point, the European Neighbourhood Policy document under the heading 'Migration and Mobility', states that "Important achievements were recorded in the Southern Neighbourhood. A Mobility Partnership between the EU and Morocco was signed in June ${ }^{4}$, the first with a southern ENP partner, and one with Tunisia was signed on 3 March 2014" [EC, (2014), p.11]. The plans for action, which complement the European Union's wider strategic policy, then set out targets to be achieved by these partners, focusing mainly on democratisation, trade and reform for good governance. In addition, they set out issue-related expectations, such as in the area of managing migration in these countries to "achieve better organisation of legal migration, to maximise the positive effects of migration on development, to effectively fight irregular migration and human trafficking, to cooperate in readmission and better border control, to promote international protection and enforcement of asylum and to promote respect for migrants' rights, including Moroccans and others who find themselves in Morocco" [EC, (2013), p.22]..$^{5}$ The fact that such a general list of expectations is so open for 
interpretation emphasises the problematic dynamic between imaginings of the definitive territorialised nation-state, the specialised expectations, and the undefined and general prescriptions. The documents leave no room for what Lefebvre identifies as social practice that does not conform to what the understandings of European experts and neatly sidestep the myriad problems arising out of notions of sovereignty. They outline expectations, formulated in the operational plans as directed towards particular countries; yet the guiding policy imagines 'southern partners' as a rather open and diffuse space with the implication that this space can be extended. It is a creation of space without.

This is amplified in a June 2015 press statement of the EU High Representative for Foreign Affairs and Security Policy, Federica Mogherini: "EU has never taken the issue of migration as seriously as we are doing now". The statement goes on to announce the EU's latest naval operation, EUNAVFOR Med: "With this operation, we are targeting the business model of those who benefit from the misery of migrants. But it's only a part of a broader strategy including the cooperation with our partners in Africa" (Mogherini, 2015). The statement seems to assume a structured and organised migration business with malevolent intent. Dubious as this assumption is (as Carling, 2007, for example, suggests), the first step to be taken, according to Mogherini, is surveillance and assessment of human smuggling and trafficking networks in the area. Thus policy making seems to rest entirely on assumptions rather than on evidence, and on interpretation of a particular kind of movement situation, without acknowledging that this interpretation is informed by what Lefebvre calls 'ideology'. There is no space allowed here for questions concerning the destructive role of European policy-making in bringing about the businesses that facilitate international movement. Further, the above suggests that there is an imagined boundary at the border to the Southern Mediterranean, after which the imaginary of diffuse 'space without' begins.

It is important to understand that such imaginings are not part of a move to re-territorialise (which would involve the construction of a bounded, institutionalised place); rather, space is both left undefined and acted on. The 'space without', neither imagined as bordered place nor as cultural space, begins with the European external border and expands outwards. Once again, there are images to illustrate this point. In the popular press, images of trucks full of young men in the Sahara make this notion of diffuse space tangible; national boundaries are not at stake here. Yet, it is not only diffuseness that drives the EU's imaginaries. Another category of image - the portrayal of impenetrability - extends the spectrum of influences on European imaginings of transit space as 'space without'. We see images of narrow-laned medinas in which possibly illicit transactions are planned, in which illegal migrants can hide and disappear temporarily, and in which the rule of law is replaced by barter over services and prices, including in the trade in human beings. We also see pictures of people living rough in the mountainous areas of Morocco, dark, with high trees - distinctly untransparent and difficult terrain for surveillance purposes.

These imaginings, or representations, then enable the European Union to propose single-minded policies, such as the destruction of boats used by smugglers, and disables empathy with illegal migrants or any possibility of thinking about them as subjects and agents. As indicated above, the logic of transit space as 'space without' is generalisable, as Australia shows in its dealings with Indonesia (see also Missbach and Philips in this issue). Lefebvre describes this as alien space, which is abstract space that is quasigeometric, yet without a clear idea of its contours and ordered only by abstract notions 
(such as the vastness, the darkness, the impenetrable narrowness of the transit space set against the concreteness of well-governed space, quarantined space and values to be implemented). Such imaginings disable our ability to think about the space, in which a dynamic variety of relationships are taking place. In the following, I turn to questions of how such imaginings constitute claims to authority over knowledge and an ephemeral politics and sociality.

\section{Space and ephemeral acts of autonomy - creative space}

Lefebvre's critique of conceptions of space, which I have made use of above, is important. The two modes of analysis on which the European Union and its migration experts seem to base the construction of their imaginings of space fall short of what Lefebvre wants to grasp as the 'contradictory space' that opens up the possibility for creativity. "Social space embodies distinct and distinctive 'traits' which attach to the 'pure' mental form of space... Their analysis tells us what it is that confers a concrete (practical) existence upon space instead of leaving it confined within (mental) abstraction" [Lefebvre, (1991), p.292]. He explains:

The thought of technocrats oscillates between the representation of an empty space, quasi geometric, occupied only by concepts, by logics and strategies at the highest rational level - the representation of a space finally filled, occupied by the results of these logics and strategies. They do not perceive that in the first place all space is produced, and consequently that this product does not come from conceptual thought that is not immediately a productive force. [Lefebvre, (1956), p.36]

Here, I do not read 'productive force' in the strictly Marxist sense of the relations people need to enter into in order to survive, as this implies a much more regulated and directed activity, but rather as a space of interaction in which publicity, solidarity and violence are made. Space in this understanding is a constellation in which appearance is realised, in the sense of Arendt's 'worldliness'. It is a constellation insofar as people come together in public space, meeting and acting based on what Arendt (1998) terms 'inter-esse'. For Arendt, what is relevant is not inter homines esse (being among men), as this is not understood as political, but inter-esse homines (being with others), which is political a space of appearance [Arendt, (1998), p.50] in which worldliness unfolds.

Arendt envisages political space and time where, as soon as it appears, 'someone' opens up, introduces himself, shares of himself; this is the space and time of Öffentlichkeit, publicity and opening ... of the unthought, the forgotten, the repressed, ...; the space and time of the public's Becoming, of "publicity" where the unspeakable and the invisible seem straightaway signifiable. (Kristeva, 2006)

It is space in which what is legitimate, and what is not, is shifting, debated and contested (Arendt, 1964a). Worldliness is contestation of repressive power and rejection of coercive authority [Springer, 2011; Jun, (2010), p.51]. Contestation is judgement of, for example, the authority of bureaucracy, which is problematic precisely because it is so abstract, as shown above. It is anonymous and acts on space (-making), without respect for nuance or Lefebvre's 'traits' of the concrete. Springer, drawing on Arendt, explains that 
Public space is understood as the battlefield on which the conflicting interests of the rich and poor are set, as well as the object of contestation. Within this realm, violence is acknowledged as both an outcome of attempts to impose an 'ordered' view of public space originating 'from above', and often as an act of resistance 'from below' by those seeking radical democratic spaces of 'unscripted' interaction. [Springer, (2011), p.526]

My claim here is that transit space is such a contested public space. It is a physical space that is needed to enable people to come together, and it is a space that is capable of different kinds of violence, but ultimately it enables world through inter-esse, in the sense of inter-esse homines. Such a constellation, this worldliness, needs to be understood as conflicted insofar as both authority and autonomy need to be interrogated as elements constructing the transit space, or, in Lefebvre's words, as constructing 'contradictory space'. In order to unpack this thought, I turn briefly to a discussion of authority, which is followed by more detailed consideration of the problem of autonomy.

Authority is not neutral and, as such, my use of the word begs the question of what is 'good' authority and what is 'bad' authority. This question is relevant, as authority can either enable or inhibit autonomy. Furthermore, those coming together in the transit space cannot easily be differentiated between as those holding and acting on authority or those holding and acting on autonomy. There is a need for evaluative clarification. Jun (2010) points out that, if coercive authority is 'bad', what the coercion consists of needs to be identified. He explains that coercive does not just mean "the de facto capacity to exercise power over others, but also the de jure license or warrant to exercise power over others" [Jun, (2010), p.52]. In the scenarios of the transit space, I have already analysed European imaginings and the resultant enforcement of policy as 'abstracted space' in which the European Union and its migration experts impose their standards and thus their authority via a mix of 'incentives' and conditionality, despite the rhetoric of 'partnership'. The hegemonic logic and the relatively powerful geopolitical positioning of countries of the Global North enable their assertion of authority over the 'partners' and thus the conditions in which the presumed illegal migrants act. This is done rather indirectly, as, in Jun's words, relationships of opaque authority are established, which "is arbitrary, [and] in turn implies that people have no reason to recognise its power over them" [Jun, (2010), p.52]. On the one hand, the logic of illegality is normalised; on the other hand, the logic of designating Southern neighbours as safe (for migrants), but still in need of greater effort to democratise and implement the rule of law, seems to be agreed upon. Given that both these logics are almost universally accepted, EU policy making vis-à-vis its North African neighbours is part of normal foreign policy relations and is not considered, at least not publicly, problematic. At the same time, the ways in which this is enacted and practised is made opaque by the use of words such as co-operation (for example, in combined policing efforts) and capacity-building (for example, by providing technical assistance).

European dictate is bureaucratic violence; it is distant and anonymous, which, in Hannah Arendt's view, makes it so much worse because it removes the potential for answerablity (Arendt, 1964b). An example might illuminate this point: The border fence around Melilla on the continent of Africa bracketing bits of left-over colonial territory still held by Spain is an advanced security solution, and is considered a humane construct as it did not have razor wires when it was installed. The fence abutting Moroccan territory is bent outwards and has a movable section on top to trap anyone who makes it up that far. Between the fences there is metal mesh which tenses on contact, trapping 
anyone who jumps or falls onto it. Then there is a small fence and another tall inner fence. The 'humane' construct also boasts movement detectors, cameras and the capacity to spray peppered water in case of a bigger assault. Although it may not lacerate a person, as razor fences do, it is still capable of killing. It is funded by the Spanish Government and the European Union [Andersson, (2014), pp.89-130]. This is bureaucratic violence, ordered and constructed at arms length, controlled by anonymous functionaries behind screens. Europeans do not need to get into personal contact; there is no inter-esse in either sense of the word. There is little room for worldliness; it is unlikely there will be any witnesses to create publicity, no one to look into the eyes of the 'humanely' deterred and to hear their contestation. Overall, though, this is domination both in its aggressive form and in its assumed entitlement to speak and make decisions for others - it is opaque. It denies people the capacity for inter-esse, for becoming public, for introducing and sharing one's full complexity as a person, and for dissenting. Jun draws on Goldman (1998) to explain that opaque authority violates the self-respect and autonomy of not only the migrant who happens to have arrived in this particular space, but also all others who inhabit this space and are with those myriad others.

Another form of coercive authority is enacted more directly, though no less arbitrarily, by state institutions that are pressed to implement agreed reforms. This is not to say that the violence enacted here is less relevant; it is to say that such violence is of a different order, being physical and direct. For example, in raiding a camp where people live rough, the police enjoy almost total impunity in their dispersal and arrest practices. Guards in places of detention have almost total impunity when they take payments to turn a blind eye when someone wants to make a break. Missbach and Sinanu (2012) illustrate this vividly, drawing on fieldwork in Indonesia. The direct contact changes the dynamic; it is physically more violent than a border fence, but this violence is not opaque. In a situation of direct contact, there might be the possibility, however faint, for sharing oneself in a way that is difficult to be ignored. There is the possibility of judgement, of fleeting moments of autonomy against coercive authority.

In another example, there is the coercive authority of those who are not in a formal (governmental) position, who offer knowledge and services to facilitate onward journeys. These facilitators hold authority by offering a transaction. This activity is criminalised as smuggling (with an assumption of criminality directed at the migrant who buys the services) or trafficking (with an assumption of deception of the unassuming person who is moved across borders). Either way, arguably there is the potential for coercion and violence in such transactions and services. While these practices are not new, they have become more pronounced and more dangerous because of the Global North's policy and practice of transit space. Jun categorises this kind of coercive authority as de jure licence. Yet, it is also this category that makes the notion of contradictory space most tangible; wherever people are forced to be immobile, there will be activities to break their immobility, in this context by enacting an illicit economy around the attempt to move across borders, where coercive formal authorities deem such crossing illegitimate.

In the case of transit space, then, the seemingly clear-cut dynamics of powerful actor versus victim are suspended. Acts of autonomy here need to be understood at the same time more radically and more humbly; they are ephemeral acts made possible in public concert with risks of violence attached as well as having generative potential. They take place in relation to a violent order imposed by the European Union alongside competing orders generated domestically and in relation to regional dynamics of the South and globalisation more generally. Autonomy and worldliness in the transit space are 
ephemeral acts in the dynamic between the imposition of abstracted space and unscripted worldliness. Relationships are temporal, movable and breakable.

I am not using autonomy here in the sense of its use by the 'autonomy of migration' school of thought (Rodríguez, 1996; Mezzadra and Neilson, 2003; Mezzadra, 2004; Papadopoulos et al., 2008; Nyers, 2011; Khosravi, 2010; De Genova, 2010). The 'autonomy of migration' literature draws on Marxist traditions. It focuses on political agency and migrants' capacity to subvert and therefore transform their context, drawing on experience and action in order to challenge sovereign power and citizenship, understood in the narrow sense of the territorial nation-state (McNevin, 2013). This intellectual engagement with international migration, and in particular with illegal migration, is, in part, a reaction to much of the literature of international relations, which is focused on control producing the securitised subject and its abjection and often draws on Giorgio Agamben as inspiration for analysis (Edkins and Pin-Fat, 2005; Hyndman and Mountz, 2008; Andrijasevic, 2010; Rygiel, 2011). Mobility in the 'autonomy of migration' school of thought is conceptualised as preceding control. Acts of resistance are accorded such powerful momentum that "the state cannot respond by expanding its inclusion practices; instead a fundamental transformation of the state's own structure is initiated" [De Genova and Peutz, (2010), p.14]. Most welcome as that would be, the linear, often individualised, logic of this conceptualisation belies practices concerning transit space which seem to point in a rather different direction, in which space is more and less regulated and in which clear assignations of directed, rational subjectivity might be romantic. ${ }^{6}$

Subjectivity can be read as a distinctly spatial construct. It is seen as a structural gap within the order of language than becomes contingently occupied by the acting individual (Howarth, 2013). In other words, the subject is the place, co-constitutive of spatial relations and subjectification, with which individuals come to identify and are identified, but it remains contradictory, in a similar way to the context of space discussed above. The political act is a coming into this place by way of problematising the assigned role (Rancière, 2004) as, for example, being illegal and hunted, and becoming public (Arendt, 1998) and worldly, rather than either submitting to it or overthrowing it as an act of rationality and self-control. This is the making visible of the structural gap, the moment when the political order is shown to be less than coherent and the agreed order is shown to be as contradictory as the subjects are. Such moments of rupture can lead to demands to be counted and to be representative of an alternative universal (Newman, 2007). Here, I am thinking of those migrants who stage themselves with posters inscribed with slogans such as 'we are humans', 'we have dignity', 'we won't go back', as seen in the media. Yet, these are not acts that necessarily transform authority's structures, as De Genova suggests. They are ephemeral acts of contestation and creativity. They are ephemeral acts of worldliness made possible by the particular, contradictory, space that transit is.

\section{Social embryos of political existence?}

The universal emerges in a contingent way. It can emerge by staging visibility in the transit space, such as through the posters demanding to 'open the way'. However, this can only be a momentary, fleeting moment in which the world of abstract space and the world of autonomous acts become visible to each other, as the longer staging of such 
visibility would lead to authority's violence - the staging of European order. In this case, worldliness would be undermined and coercion would reign uncontested. Equally, the deliberate turning away - that is, refusing to submit to such order - can lead to ephemeral moments of an autonomous act, as authority collapses without its recognition and scripted submission and response. Coercion relies on agreement in an asymmetrical relationship: if the illegal person 'talks back' as an equal, when, for example, facing the police in a raid, there will be a moment of surprise, maybe hesitation - a recognition takes place. Transit space is, then, space in which there are moments of "absence of coercive authority and absence of concentrated power exercised 'from the top down"” [Jun, (2010), p.54]. This does not mean that coercive authority is removed. Yet, these moments enable a beginning, a momentary glimpse of an embryonic social. Or, put differently, they allow glimpses of a struggle for equality, defined here by drawing on Proudhon "as an ideal state of affairs that is both desirable and realisable" [Jun, (2010), p.54]. This state of affairs implies 'freedom to be', the ability to speak and act for oneself, as witnessed by and in community with others, in all the variety of ways that people establish worldliness. Thus, it is a collective process of making social space in which the subject comes to be and act, and, in turn, produces space. This constellation needs the physical space for people to come together, collaborate and appear as legitimate claimants (Springer, 2011). Such recognition might lead to a different outcome than violence of arrest, physical violence and deportation back into the Saharan desert (Collyer, 2010), although it might just as likely lead to no more than a moment's hesitation. In both the visible and the withdrawal, there is a claim to a particular universality, which is constructed around the idea of equality of legitimately inhabiting space in both senses of inter-esse (being among and with others) as horizon. For this kind of autonomy to make sense, collectivity is needed, and this collectivity is realised in space. Autonomy in this sense is the capacity to come out and be worldly in the social space; thus, transit space becomes creative space that can bring about political existence.

There is no doubt about the abjection that is part of the reality of transit space: when migrants crossing the desert are robbed by gangs and left naked and without food; when they are dumped by Moroccan authorities at the Algerian border, beaten and humiliated after raids; when they are deceived by both legitimate actors (for example, Spanish authorities) and illegitimate (from the point of view of European order) actors with promises to take them to the European mainland only to find themselves deported or stationary and relieved of their meagre funds; when people have slowly grown into their subjectivity of the hunted illegal, which has grave impact on mental health, by walking in certain ways, being constantly alert and observing their environment (Andersson, 2014; Johnson, 2014). This kind of abjection is created in the undefined space that constitutes transit, as shown in the examples above, and not in relation to a specific place or to a specific person. It is devoid of any relation of answerability. It is the abstract and intangible that creates abjection. Yet, this is only part of the story.

The other part is duly ignored by those imagining abstract space, whenever possible. It is the story of migrants mirroring governance structures, building communities by electing their own 'governments', establishing mid-way houses and ghettos, supporting each other with information, working with police and border guards, finding creative ways to circumvent the 'humane' security solutions put up by the EU. It is the story of a politics of ephemeral acts and moments in which the dominant order is either challenged or ignored and sidelined. These short-term communities are not altruistic. 'Pushers' or 'facilitators' in Niger (Lucht, 2013) or Mauritania (Andersson, 2014) are, more often than 
not, people who are themselves on the journey, have been unsuccessful, learned, lost money and are now regaining funds to move again from those currently on the move. Ghettos are run by people who might have been in one place longer than others and collect a fee that admits and protects. After a while, they are off and someone else takes over (Johnson, 2013). Johnson (2014, pp.151ff) calls these 'communities of mobility', since, even if people find themselves temporarily immobile, the idea of movement is always present for most of them (Andersson, 2014). Importantly, the persistent presence of movement does not inevitably mean these people strive to head towards Europe. Yet, if they do, the communities show solidarity in organising attacks on the fences together, in organising who goes begging or selling goods, and thus have an eye on their group's protection. There is no claim for fundamental structural change, but there is a 'space apart' - one of political existence.

Thus, this scenario begs the question of which order is actually illicit? Governments of EU member states and the European Union itself offer incentives to African Governments and police forces to enact their border paranoia, such as security gadgets, study visits and work visas, financial support for civil society and international non-governmental organisations, in a cynical parody of working towards human rights and protection (Gammeltoft-Hansen and Sørensen, 2013; Andersson, 2014) in an effort to hunt the elusive black, young man who looks like a candidate for illegal migration on the basis of supposed intentionality (Andersson, 2014). These governments invest in myths and fantasies of (in)security by pouring money into the defence industry to supply products for 'humane' security solutions that cost millions of euros of taxpayers' money. Civil society organisations happily accept European funding to spread the word about the dangers of the journey (Andersson, 2014). Is this not also illicit and deeply violent? Or is this acceptable because our governments are democratically elected and our civilised world accepts that the monopoly of violence rests in the hands of the sovereignty we trust?

\section{Conclusions}

At the start of this article I made the statement that the idea of transit is a fair-weather policy instrument. By that I mean that transit space is relevant in situations when the geographic neighbourhood, as demarcated by the big geopolitical boundaries between the Global North and the Global South, is not challenged by immediate war and conflict such that the Global North is induced to pay attention. As the current situation in Europe, with the many thousands of refugees from Syria and elsewhere, shows, if there is geopolitical conflict of such severity that people just move, there is at least a core of European countries that act on the values they proclaim and offer protection, irrespective of the perceived strain such action brings. Other European countries seem unwilling to set their navel-gazing attitude aside. Sooner or later, governments will draw back from their narrative of mixed flows and return to using the transit space, as evidenced by EU negotiations with Turkey over Syrian refugees. It is for this reason that I think it is important to clarify what transit space is and to recognise it not only as a space of abjection, but also as a space in which ephemeral acts of worldliness are possible, however violent they may be. In this conceptualisation, transit space is interesting for its capacity to constitute the social embryos of political existence. 
The constellation we are looking at is contradictory space, being both:

1 abstract space (Lefebvre): it is controlled by an order-imposing authority which seeks to suffocate its openness and in which abjection and death are outcomes; and

2 creative space (Arendt/Springer), in which people have inter-esse, which produces ephemeral moments in which no-one is entitled and able to impose authority. It is agonistically inclusive but can turn violent.

Space in this reading is marked by ephemeral relationships: fleeting, dissolving, temporally intangible. It can be both violent and social, in a kind of solidarity. The communities that make and are made by such a space are transgressive and ephemeral in character; they are communities that act with, within and on spaces that are not exclusively pre-designed by sovereign-coercive power but interact with it. What is important here is to understand that EU policies are simultaneously the condition of possibility for the particular kind of illegality of the transit space (abjection) and the condition of possibility for ephemeral space (solidarity/creativity). It is a space that is marked by autonomy - the freedom of speaking for oneself, reinventing oneself and presenting oneself to others to form world - however precarious this is in terms of the becoming and dissolving of social power.

There is no expectation on anyone's part in these spaces to establish hegemony and to sacrifice freedom for a higher force (for example, the state). These collectives are not and cannot be sufficiently institutionalised to subordinate, as they are a communities of people who simply want to move. They form a community of practice that is constituted inter-relationally, marked by continuous reconfiguration, breakdown without crisis, openness to changed relations and new people, and occasional engagement in political negotiations, violent and otherwise. Transit space is contradictory space; what makes it political is the appearance of interaction of logics with practices of both violence and solidarity in which the domination of one order is undermined without establishing another order. Definitions of what is licit and what is illicit are suspended, or at least thrown open to question. This makes transit space important. Scepticism is in order before judging transit space exclusively as abject, criminal and threatening, as such judgment sits firmly in the authoritarian imaginings that drive destructive and uninformed European policy.

\section{Acknowledgements}

Earlier drafts of this paper were presented at a workshop held by the RGS-IBG and the University of Birmingham. It has subsequently benefited from comments received from Ruth Kinna and the participants of a workshop organised by Melissa Philips and Antje Missbach at the Humboldt University, Germany. All mistakes and any remaining lack of clarity are my responsibility.

\section{References}

Ambroso, G. (2012) 'Bordering on a crisis', Forced Migration Review, No. 39, pp.6-7.

Andersson, R. (2014) Illegality, Inc.: Clandestine Migration and the Business of Bordering Europe, University of California Press, Oakland. 
Andrijasevic, R. (2009) 'Sex on the move: gender, subjectivity and differential inclusion', Subjectivity, Vol. 29, No. 1, pp.389-406.

Arendt, H. (1964a) 'Hannah Arendt im Gespräch mit Günther Gaus', Zur Person, 28 October [online] https://www.youtube.com/watch? $\mathrm{v}=\mathrm{dsoImQfVsO} 4$ (accessed 12 March 2016).

Arendt, H. (1964b) Hannah Arendt im Gespräch mit Joachim Fest, 9 November. https://www.youtube.com/watch?v=GN6rzHemaY0 (accessed 12 March 2016).

Arendt, H. (1998) The Human Condition, University of Chicago Press, Chicago.

Betts, A. and Milner, J. (2006) The Externalisation of EU Asylum Policy: The Position of African States, COMPAS Working Papers 06-36, Centre on Migration, Policy and Society, Oxford.

Bigo, D. (2014) 'The (in)securitization practices of the three universes of EU border control: military/navy-border guards/police-database analysts', Security Dialogue, Vol. 45, No. 3, pp.209-225.

Bredeloup, S. (2012) 'Sahara transit: times, spaces, people', Population, Space and Place, Vol. 18, No. 4, pp.457-467.

Carling, J. (2007) 'Migration control and migrant fatalities at the Spanish-African borders', International Migration Review, Vol. 41, No. 2, pp.316-343.

Collyer, M. (2010) 'Stranded migrants and the fragmented journey', Journal of Refugee Studies, Vol. 23, No. 3, pp.273-293.

Collyer, M. and de Haas, H, (2012) 'Developing dynamic categorisations of transit migration', Population, Space and Place, Vol. 18, No. 4, pp.468-481.

Collyer, M., Düvell, F. and de Haas, H. (2012) 'Critical approaches to transit migration', Population, Space and Place, Vol. 18, No. 4, pp.407-414.

De Genova, N. (2010) 'The queer politics of migration: reflections on 'illegality' and incorrigibility', Studies in Social Justice, Vol. 4, No. 2, pp.101-126.

De Genova, N. and Peutz, N. (Eds.) (2010) The Deportation Regime: Sovereignty, Space and the Freedom of Movement, Duke University Press, Durham NC; London.

de Haas, H. (2006) 'Trans-Saharan migration to North Africa and the EU: historical roots and current trends', Migration Information Source, 1 November [online] http://www.migrationpolicy.org/article/trans-saharan-migration-north-africa-and-eu-historicalroots-and-current-trends (accessed 10 March 2016).

de Haas, H. (2008) 'The myth of invasion: the inconvenient realities of African migration to Europe', Third World Quarterly, Vol. 29, No. 7, pp.1305-1322.

Doty, R.L. (2011) 'Bare life: border-crossing deaths and spaces of moral alibi', Environment and Planning-Part D, Vol. 29, No. 4, pp.599-612.

Düvell, F. (2005) 'Globalization of migration control: a tug-of-war between restrictionists and human agency?', in Henke, H. (Ed.) Crossing Over: Comparing Recent Migration in the United States and Europe, pp.23-46, Lexington Books, Lanham.

Düvell, F. (2012) 'Transit migration: a blurred and politicized concept', Population, Space and Place, Vol. 18, No 4, pp.415-427.

Edkins, J. and Pin-Fat, V. (2005) 'Through the wire: relations of power and relations of violence', Millennium: Journal of International Studies, Vol. 34, No. 1, pp.1-24.

European Commission (EC) (2013) Relations avec le Maroc: Project de Plan d'Action Maroc pour la Mise en Oeuvre du Statut Avancé (2013-1017), Dossier interinstitutionel: 2013/0107 (NLE), Brussels [online] http://eeas.europa.eu/enp/pdf/pdf/action plans/ morocco_enp_ap_final_en.pdf (accessed 12 March 2016).

European Commission (EC) (2014) Neighbourhood at the Crossroads: Implementation of the European Neighbourhood Policy in 2013, Join(2014)12 final, Joint Communication to the European Parliament, the Council, the European Economic and Social Committee and the Committee of the Regions, Brussels [online] http://eeas.europa.eu/enp/pdf/2014/ joint_communication_en.pdf (Accessed 12 March 2016). 
Faist, T. (2012) 'Migration', in Ritzer, G. (Ed.): Wiley-Blackwell Encyclopedia of Globalization, Blackwell, Oxford.

Gammeltoft-Hansen, T. and Sørensen, N.N. (Eds.) (2013) The Migration Industry and the Commercialization of International Migration, Routledge, Abingdon.

Goldman, E. (1998) Red Emma Speaks, 3rd ed., Humanity Books, Amherst, New York, NY.

Howarth, D.R. (2013) Poststructuralism and After: Structure, Subjectivity and Power, Palgrave Macmillan, Basingstoke.

Huysmans, J. (2006) The Politics of Insecurity: Fear, Migration and Asylum in the EU, Routledge, Oxford.

Hyndman, J. and Mountz, A. (2008) 'Another brick in the wall?: neo-refoulement and the externalization of asylum by Australia and Europe', Government and Opposition, Vol. 43, No. 2, pp.249-269.

Johnson, H. (2013) 'The other side of the fence: reconceptualizing the 'camp' and migration zones at the borders of Spain', International Political Sociology, Vol. 7, No. 1, pp.75-91.

Johnson, H. (2014) Borders, Asylum and Global Non-Citizenship: The Other Side of the Fence Cambridge University Press, Cambridge.

Jones, R. (2009) 'Categories, borders and boundaries', Progress in Human Geography, Vol. 33, No. 2, pp.174-189.

Jun, N. (2010) 'Anarchist philosophy: past, problems and prospects', in Franks, B. and Wilson, M. (Eds.): Anarchy and Moral Philosophy, Palgrave Macmillan, Basingstoke.

Khosravi, S. (2010) 'An ethnography of migrant 'illegality' in Sweden: included yet excepted?', Journal of International Political Theory, Vol. 6, No. 1, pp.95-116.

Koser, K. and Lutz, H. (Eds.) (1999) The New Migration in Europe: Social Constructions and Social Realities, Macmillan, Basingstoke.

Kristeva, J. (2006) 'Hannah Arendt or refoundation as survival', Hannah Arendt Prize for Political Thought, 15-16 December, Bremen [online] http://www.kristeva.fr/Arendt_en.html (accessed 12 March 2016).

Lefebvre, H. (1956) Pignon, Editions Falaise, Paris.

Lefebvre, H. (1991) The Production of Space, translated by D. Nicholson-Smith, Blackwell, Oxford.

Lucht, H. (2013) 'Pusher stories: Ghanaian connection men and the expansion of the EU's border regimes into Africa', in Gammeltoft-Hansen, T. and Sørensen, N.N. (Eds.): The Migration Industry and the Commercialization of International Migration, Routledge, Abingdon, pp. 173-189.

McNevin, A. (2013) 'Ambivalence and citizenship: theorising the political claims of irregular migrants', Millennium: Journal of International Studies, Vol. 41, No. 2, pp.182-200.

Mezzadra, S. (2004) 'The right to escape', Ephemera, Vol. 4, No. 3, pp.267-275.

Mezzadra, S. and Neilson, B. (2003) 'Né qui, né altrove: migration, detention, desertion: a dialogue, Borderlands E-journal, Vol. 2, No. 1, pp.1-40.

Missbach, A. and Sinanu, F. (2012) "The scum of the earth'? foreign people smugglers and their local counterparts in Indonesia', Journal of Current Southeast Asian Affairs, Vol. 30, No. 4, pp. 57-87.

Mogherini, F. (2015) Council Launches EU Naval Operation to Disrupt Human Smugglers and Traffickers in the Mediterranean, European Council press release, 22 June [online] http://www.consilium.europa.eu/en/press/press-releases/2015/06/22-fac-naval-operation/ (accessed 12 March 2016).

Mountz, A. and Kempin, R. (2014) 'The spatial logics of migration governance along the southern frontier of the European Union', in Walton-Roberts, M. and Hennebry, J. (Eds.): Territoriality and Migration in the E.U. Neighbourhood: Spilling Over the Wall, pp.85-95, Springer, Dordrecht. 
Newman, S. (2007) Unstable Universalities: Poststructuralism and Radical Politics, Manchester University Press, Manchester.

Nyers, P. (2011) 'No one is illegal between city and nation', Studies in Social Justice, Vol. 4, No. 2, pp.127-143.

Oelgemöller, C. (2010) 'Transit' and 'suspension': migration management or the metamorphosis of asylum-seekers into 'illegal' immigrants', Journal of Ethnic and Migration Studies, Vol. 37, No. 3, pp.407-424.

Oelgemöller, C. (2011) 'Informal plurilateralism: the impossibility of multilateralism in the steering of migration', British Journal of Politics and International Relations, Vol. 13, No. 1, pp.110-126.

Papadopoulos, D., Stephenson, N. and Tsianos, V. (2008) Escape Routes: Control and Subversion in the Twenty-First Century, Pluto Press, London.

Rancière, J. (2004) Disagreement: Politics and Philosophy. University of Minnesota Press, Minneapolis.

Rodríguez, N. (1996) 'The battle for the border: notes on autonomous migration, transnational communities, and the state', Social Justice, Vol. 23, No. 3, pp.21-37.

Rygiel, K. (2011) 'Bordering solidarities: migrant activism and the politics of movement and camps at Calais', Citizenship Studies, Vol. 15, No. 1, pp.1-19.

Schapendonk, J. (2009) 'Moving and mediating: a mobile view on sub-Saharan African migration towards Europe', in Fernandez-Ardevol, M. and Ros Hijar, A. (Eds.): Communication Technologies in Latin America and Africa: A Multidisciplinary Perspective, pp.293-318, IN3, Barcelona.

Schapendonk, J. (2012) 'Migrants' im/mobilities on their way to the EU: lost in transit?' Tijdschrift voor Economische en Sociale Geografie, Vol. 103, No. 5, pp.577-583.

Squire, V. (Ed.) (2010) The Contested Politics of Mobility: Borderzones and Irregularity, Routledge, Oxford.

Springer, S. (2011) 'Public space as emancipation: meditations on anarchism, radical democracy, neoliberalism and violence' Antipode, Vol. 43, No. 2, pp.525-562.

Tazzioli, M. (2015) Spaces of Governmentality: Autonomous Migration and the Arab Uprisings, Rowman \& Littlefield, London; New York.

van Houtum, H. (2010) 'Human blacklisting: the global apartheid of the EU's external border regime', Environment and Planning-Part D, Vol. 28, No. 6, pp.957-976.

Walters, W. (2004) 'Secure borders, safe haven, domopolitics', Citizenship Studies, Vol. 8, No. 3, pp.237-260.

Weiner, M. (1992) 'Security, stability, and international migration', International Security, Vol. 17, No. 3, pp.91-126.

Wolff, S. (2014) 'The Politics of negotiating EU readmission agreements: insights from Morocco and Turkey', European Journal of Migration and Law, Vol. 16, No. 1, pp.69-95.

\section{Notes}

1 I consciously use the term 'illegal migrant' to indicate that this category is a legal construct imposed by governments making law and acting on it, rather than any of the more benign terms to designate those mobile people crossing or attempting to cross borders in what is often defined as an illicit act.

2 My use of 'we' in conjunction with 'European' is justified by a poststructuralist approach, in which my own positionality is that of a privileged European passport holder as well as participant in expert discourses on international migration. As such, my focus is on Europe and European discourse as an amalgam emerging out of interactions between EU institutional 
practices and EU country narratives, making meaning that is then projected both as universal, but contested, and directed towards the European neighbourhood.

3 In this 2010 article, I have critically reviewed scholarly arguments and policy instruments to show the discursive construction of the transit country and its effects; here, I draw on this article to take the opportunity to think more concretely about the kind of space that is created.

4 One of the major agreements in this policy related to the return of any migrant reaching European territory through Morocco, irrespective of nationality.

5 Author's translation from the French original.

6 See Mezzadra (2004) for a more subtle discussion of subjectivity. 